\title{
Stochastic simulation of live salmonid movement in England and Wales to predict potential spread of exotic pathogens
}

\author{
Mark Thrush*, Edmund Peeler \\ Centre for Environment, Fisheries and Aquaculture Science, Barrack Road, The Nothe, Weymouth, Dorset DT4 8UB, UK
}

\begin{abstract}
The anthropogenic movement of live fish has been identified as the most important route for the transmission of disease between river catchments. To assist in contingency planning for exotic salmonid disease outbreaks, a stochastic model was developed to assess the potential geographic distribution of an introduced pathogen with time to first detection. The Live Fish Movement Database (a resource funded by the UK Department for Environment, Food and Rural Affairs [Defra] and managed by the Centre for Environment, Fisheries and Aquaculture Science [CEFAS] and the Environment Agency [EA]) was used to establish details of live fish movement in England and Wales. A contact network was created for farm to farm and farm to non-farm (fishery) movements of rainbow trout Oncorhynchus mykiss, brown trout Salmo trutta and Atlantic salmon Salmo salar, and probability functions were used to model the timing and destination of movements from farm sites, based on these trading activities. Monte Carlo simulations were run to track the progression of potential disease transmission from single index farm inputs through river catchments with time. Two hundred farms exported fish to 1653 destinations in 147 of the total 198 river catchments. The median number of catchments contacted after 3 and 12 mo were 3 and 6, respectively. In $5 \%$ of simulations 63 or more catchments were contacted, and in $1 \%$ of simulations 75 or more catchments were contacted after 12 mo. These results may be used to underpin the development of contingency plans for exotic disease outbreaks.
\end{abstract}

KEY WORDS: Epidemiology · Monte Carlo simulation · Risk assessment · Contingency planning • Aquaculture $\cdot$ Fish disease $\cdot$ Salmonid

\section{INTRODUCTION}

The UK is free of a number of the most serious salmonid diseases that are widespread in Europe, notably viral haemorrhagic septicaemia (VHS), infectious haematopoietic necrosis (IHN) and the monogenean parasite Gyrodactylus salaris. In the event of an exotic disease outbreak, the protection of farmed and wild salmonids depends on effective contingency plans for the elimination or containment of the disease. The movement of live animals is frequently the most important route of spread, especially long distance spread, for an introduced disease (Anderson 2002, Davies 2002). A qualitative risk analysis identified the anthropogenic movement of live Atlantic salmon
Salmo salar and rainbow trout Oncorhynchus mykiss to be the most important route for the transmission of G. salaris between river catchments (Peeler et al. 2004). The main aquaculture species in England and Wales are rainbow trout and brown trout Salmo trutta, which are farmed on over 260 freshwater sites in 64 of a total 198 river catchments (Fig. 1). Considerable numbers of live fish movements occur between farm sites (mainly juvenile fish sold for on-growing) and from farm sites to recreational fisheries or open waters (non-farm sites) for restocking. Data on live fish movements provide a vital resource for forward and backward contact tracing in the event of a disease outbreak, and also make a valuable resource for a predictive model of live fish movement. 


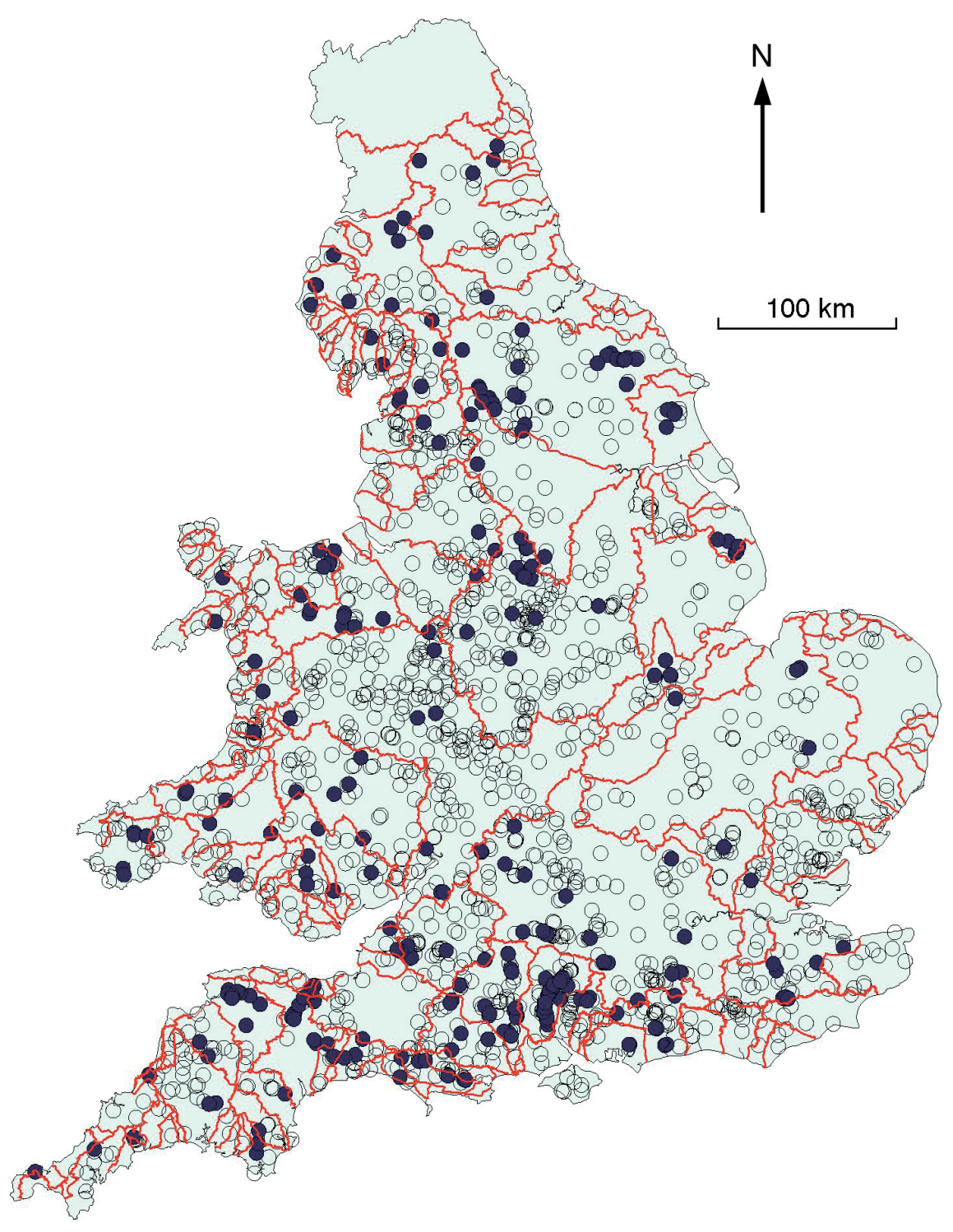

Fig. 1. Distribution of salmonid fish farm sites ( ) and non-farm sites (fisheries and open waters, O) among 198 river catchments (red borders) in England and Wales

tration, fish imports and exports, and rearing of non-native fish species. The details of farm to farm and farm to nonfarm fish movements are logged on the LFMD by CEFAS and the EA respectively.

Mathematical disease modelling is a rapidly expanding area of human and veterinary epidemiology, and examples of its use include prediction of the global impact of AIDS (May \& Anderson 1987), assessment of control strategies for the containment of an influenza pandemic (Ferguson et al. 2005) and the design of childhood mass immunisation programmes for the mumps, measles and rubella (MMR) vaccine (van der Hof et al. 2002). Control methods for outbreaks of classical swine fever (CSF) in the Netherlands have been evaluated by modelling (Jalvingh et al. 1999, Klinkenberg et al. 2003), and these techniques were used extensively to assess competing strategies for the control of foot-and-mouth disease (FMD) during and after the 2001 epidemic in the UK (Keeling et al. 2001, Woolhouse et al. 2001, Green \& Medley 2002). Although historically limited to theoretical population studies (Levy \& Wood 1992, des Clers 1993), the application of mathematical modelling to aquatic animal health has more recently been used to quantify the impact of bacterial kidney disease (BKD) on chinook salmon Oncorhynchus tschawytscha in North America (Hamel 2002), and a stochastic modelling approach was taken to quantitatively assess the risk of transferring Gyrodactylus salaris between specific

The Centre for Environment, Fisheries and Aquaculture Science (CEFAS) is the competent authority for the control of notifiable fish diseases in England and Wales. All fish farming businesses are registered with CEFAS, and farmers have a legal obligation to keep records of all movements of live fish and gametes on and off their sites and to make this information available to CEFAS Fish Health Inspectors during mandatory visits. Movements to recreational fisheries or open waters for restocking require consent from the Environment Agency (EA) under Section 30 of the Salmon and Freshwater Fisheries Act (Anonymous 1975). CEFAS maintains the Live Fish Movement Database (LFMD) to manage all data relating to fish farm regis- locations (Paisley et al. 1999, Høgåsen \& Brun 2003). To our knowledge, this is the first detailed predictive study of the potential distribution of disease on a national scale by live fish movement.

We established the trading relationships between farms and fisheries in England and Wales for salmonid fish, and used stochastic modelling techniques to assess the potential for disease spread by tracking possible transmission routes through the live fish movement contact network. No disease-specific transmission or infection characteristics were included in the model, so individual fish movements were considered to be 'dangerous contacts' and the establishment of clinical infection at destination sites was not assumed. 


\section{MATERIALS AND METHODS}

The LFMD was interrogated by standard structured query language (SQL) reports to determine all destinations of live fish movement in 2002 from each farm that was registered in the database in April 2004 for holding stocks of salmonid fish. The results were exported to MS-Excel spreadsheets (Microsoft), transformed into standardised arrays and combined to provide a movement-relationship matrix. A stochastic model was developed to project a single site-to-site contact scenario over a 52 wk period within an MS-Excel spreadsheet. For the purpose of the simulation, binomial distribution functions were used to determine when each site made a fish movement (for example, the sale of fish to another site), and destinations for movements were predicted using site-unique discrete-probability distribution equations generated directly from the movement-relationship matrix.

The model was based on the following assumptions and conditions

- Positive status was propagated by live fish movement only

- Disease specific transmission and infection characteristics were not considered

- Establishment of clinical infection at destination sites was not assumed

- Exporting sites had an equal chance of moving live fish to another site

- Exporting sites had the 'option' to make 1 fish movement each week

- Each contact (customer) associated with a particular exporting site had an equal probability of receiving fish

- Once a site (and its associated river catchment) received positive status it remained positive (there was no recovery)

- There was no temporal variation in live fish movement

Simulations were achieved using @Risk (Palisade), a risk analysis software add-on for MS-Excel. The sampling method was Latin hypercube. Sixty days (1440 h) of processing time was allocated to run the model, which was distributed between 2 Dell work stations (Intel Pentium 4, $2.4 \mathrm{GHz}, 260$ MB RAM, running Microsoft Windows 2000 5.0). This allowed a total of 522000 iterations using individual exporting (index) sites seeded with a positive status (generating 2610 scenarios for each of the 200 farm sites that exported salmonids in 2002). Positive status was passed to naïve sites by forward movement contact from the index site through successive weeks of the scenario. Additional contacts were generated by movements from any farm subsequently acquiring positive status, either directly from the index site or via one or more intermediaries. This process was automated by a Microsoft Visual Basic control macro, which substituted a different farm as the index site at the start of each new iteration. On completion of each iteration, a separate macro was used to append the contact status of all farm sites, nonfarm destinations and their corresponding river catchments to output files at 3, 6, 9 and 12 mo.

For the purpose of contingency planning, degrees of severity were assigned to outbreak scenarios. These were arbitrary; however, with consideration for the resources and manpower that would likely be required to combat the spread of an exotic disease following an introduction to the UK, categories of low, moderate and severe were assigned for the involvement of $\leq 3,4$ to 10 and $\geq 11$ catchments respectively. River catchments were ranked in order of the likelihood of sites within them receiving consignments of live fish from other farm sites.

\section{RESULTS}

Live fish were transported from 200 farm sites registered for the production of salmonid fish to a total of 1653 freshwater destinations (farm and non-farm) in England and Wales in 2002. Forty-two farms supplied 1 site only, whereas 64 farms ( $32 \%$ ) supplied fish to 10 or more destinations (Fig. 2). The maximum number of customers associated with 1 supplier was 81 . Seventyeight percent of sites received fish from 1 source only (see supplier profile, Fig. 3); however, 1 destination received fish from 19 different suppliers over the year. Sixty-one registered salmonid sites did not supply any other site with live fish; of these, 13 did not receive fish from any other site either, and would consequently play no part in the spread of disease by live fish movement.

Output scenarios generated by the model clearly showed that the potential for live fish movement to impact on the geographic distribution of a disease increases markedly with time (Fig. 4, Table 1). The median number of destinations in England and Wales (farm and nonfarm sites) contacted from single (index) site inputs increased from 5 at 3 mo to 17 at 12 mo. Following the theoretical introduction of an exotic disease, worst-case scenarios predicted by the model include 64 sites contacted at $3 \mathrm{mo}$ and 505 sites contacted at $12 \mathrm{mo}$. At the river catchment level, worst-case scenarios predicted by the model were 31 and 104 catchments contacted after 3 and 12 mo respectively (Fig. 5). In $5 \%$ of simulations 63 or more catchments were contacted, and in $1 \%$ of simulations 75 or more catchments were contacted after 


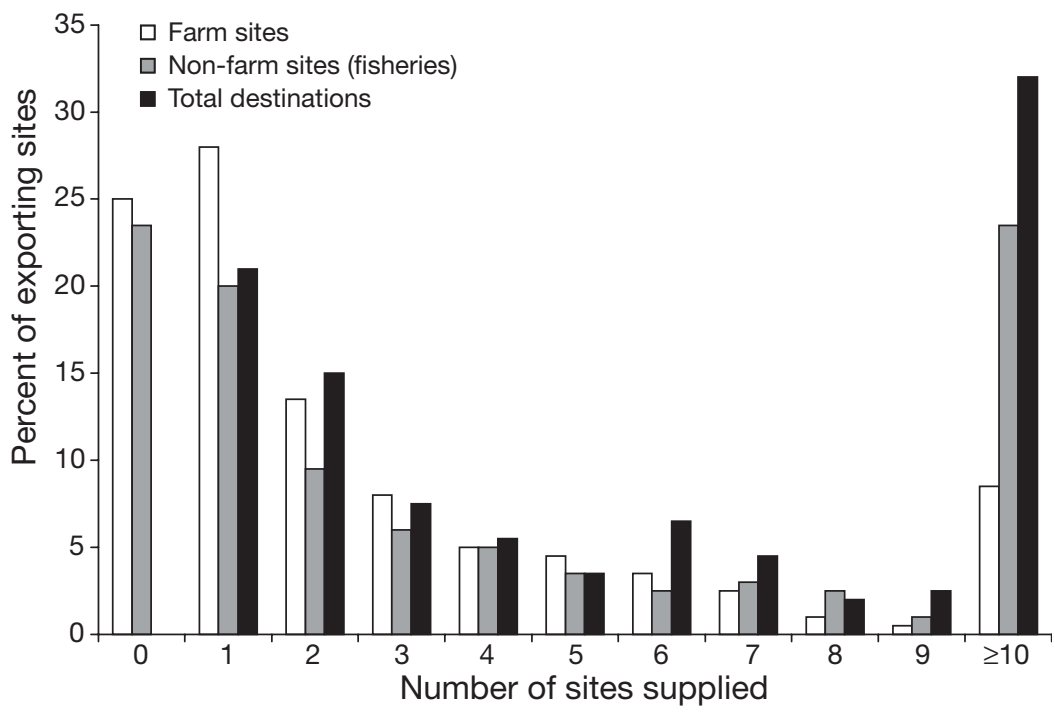

Fig. 2. Customer profile: exporting farm sites $(n=200)$ registered for salmonid stocks by number of other farm $(\mathrm{n}=260)$ and non-farm $(\mathrm{n}=1474)$ sites supplied with live fish

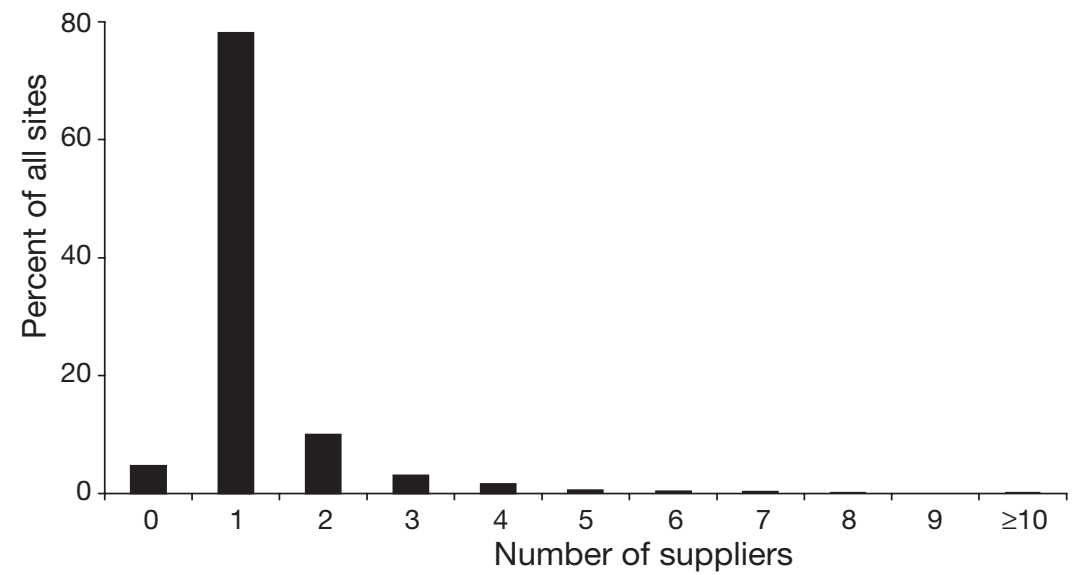

Fig. 3. Supplier profile: distribution of number of suppliers used $(n=200)$ by all destination sites

12 mo (Table 2). Assuming an introduced disease remained undetected for $3 \mathrm{mo}$, the risk of a severe outbreak (spreading to more than 10 river catchments) was $7 \%$. However, if the disease was to go unnoticed for

Table 1. Summary statistics of model output: distribution of total farm and non-farm destinations contacted at different times from 'first infection' following 522000 iterations with single farm index inputs

\begin{tabular}{|c|c|c|c|c|c|}
\hline \multirow{2}{*}{$\begin{array}{l}\text { Time from } \\
\text { first } \\
\text { infection }\end{array}$} & \multicolumn{4}{|c|}{ No. of destinations contacted } & \multirow{2}{*}{$\begin{array}{c}\text { Prob. of } \\
\text { worst-case } \\
\text { scenario (\%) }\end{array}$} \\
\hline & $\begin{array}{c}\text { Percent } \\
50 \% \\
\text { (median) }\end{array}$ & $\begin{array}{l}\text { tile va } \\
95 \%\end{array}$ & $\begin{array}{l}\text { lues } \\
99 \%\end{array}$ & $\begin{array}{c}\text { Worst-case } \\
\text { scenario }\end{array}$ & \\
\hline $3 \mathrm{mo}$ & 5 & 19 & 27 & 64 & 0.000192 \\
\hline $6 \mathrm{mo}$ & 10 & 63 & 89 & 189 & 0.000192 \\
\hline $9 \mathrm{mo}$ & 14 & 128 & 174 & 331 & 0.000192 \\
\hline $12 \mathrm{mo}$ & 17 & 206 & 275 & 505 & 0.000192 \\
\hline
\end{tabular}

$12 \mathrm{mo}$, this risk increased to over $40 \%$ (Fig. 5).

The Severn, Trent and Thames river catchments were identified by simulation to be the most likely to receive consignments of live fish. These are the 3 largest catchments by area and between them contain $28 \%$ of all sites receiving live salmonids. The 30 catchments at highest risk of disease resulting from live salmonid introduction are presented in Table 3; these include a number of catchments that support abundant wild salmon stocks, for example the Tyne and the Usk. Fiftytwo catchments were not contacted during the simulation, the majority of which did not contain farm or non-farm sites that received live salmonids in 2002. However, included with these were the Tweed and Esk. These catchments are shared with Scotland, and fall outside the jurisdiction of CEFAS and EA. Detailed records of fish movements within them are not held in the LFMD and, as a consequence, the model does not accurately represent their risk of disease introduction by live fish movement.

\section{DISCUSSION}

\section{Disease spread by animal movement}

This study is the first attempt to quantitatively assess the likely spread of an exotic fish pathogen within England and Wales via the movement of live salmonid fish. Previous trading activities were used to establish a movement-relationship matrix between farm and non-farm sites and model the po-

Table 2. Summary statistics of model output: distribution of river catchments contacted at different times from 'first infection' following 522000 iterations with single farm index inputs

\begin{tabular}{|c|c|c|c|c|c|}
\hline \multirow{2}{*}{$\begin{array}{l}\text { Time from } \\
\text { first } \\
\text { infection }\end{array}$} & $\begin{array}{l}\text { No. of } \\
\text { Percen }\end{array}$ & $\begin{array}{l}\text { catch } \\
\text { tile vo }\end{array}$ & $\begin{array}{l}\text { ments } \\
\text { lues }\end{array}$ & $\begin{array}{l}\text { contacted } \\
\text { Worst-case }\end{array}$ & \multirow{2}{*}{$\begin{array}{c}\text { Prob. of } \\
\text { worst-case } \\
\text { scenario }(\%)\end{array}$} \\
\hline & $\begin{array}{c}50 \% \\
\text { (median) }\end{array}$ & $95 \%$ & $99 \%$ & scenario & \\
\hline $3 \mathrm{mo}$ & 3 & 11 & 15 & 31 & 0.000385 \\
\hline $6 \mathrm{mo}$ & 4 & 28 & 37 & 64 & 0.000192 \\
\hline $9 \mathrm{mo}$ & 6 & 46 & 57 & 89 & 0.000192 \\
\hline $12 \mathrm{mo}$ & 6 & 62 & 74 & 104 & 0.000192 \\
\hline
\end{tabular}



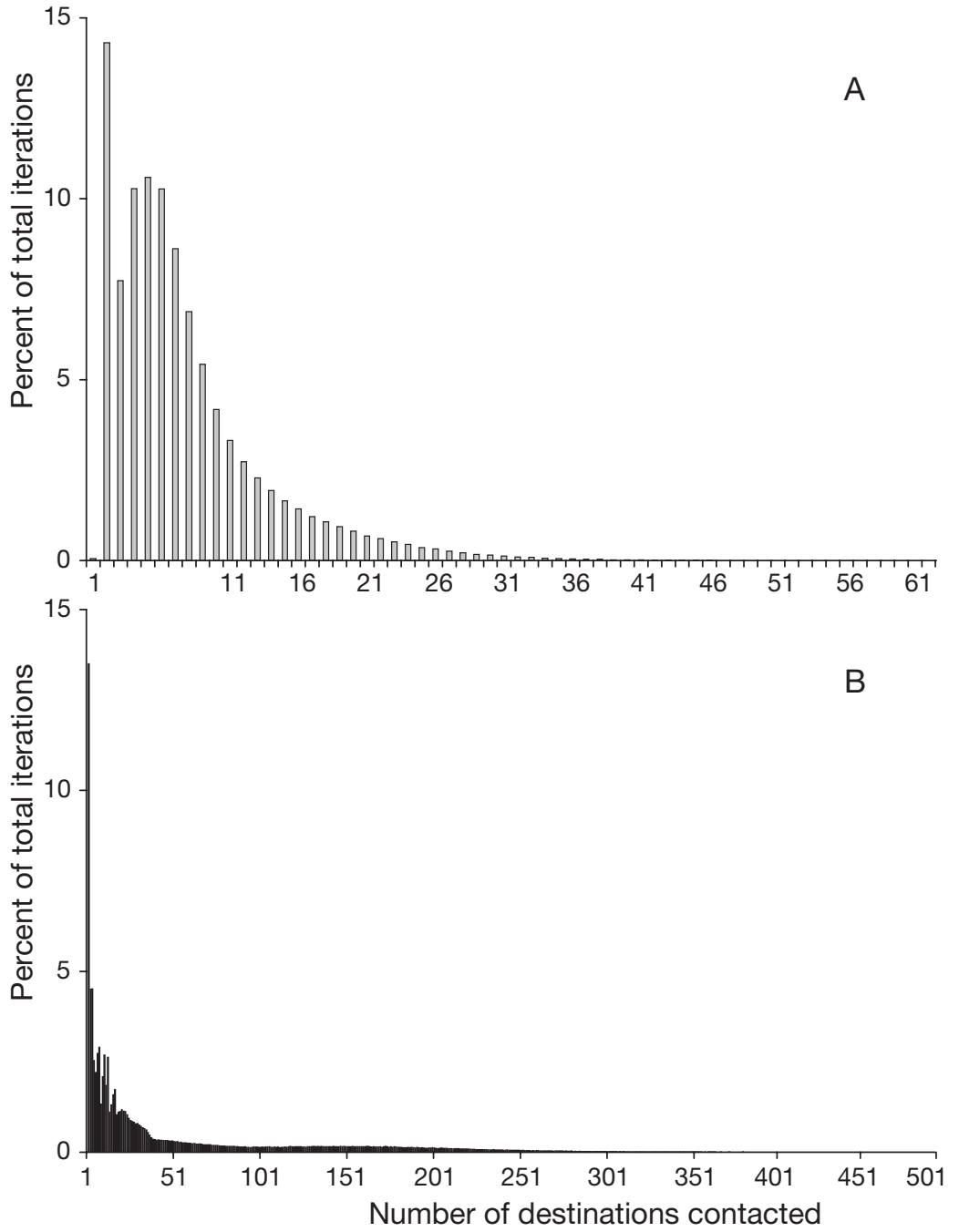

Fig. 4. Distribution of destination sites contacted after (A) 3 mo and (B) 12 mo from single index farm inputs. The $y$-axes extend to near the position of the worst-case scenarios (see Table 1) although the percentage of total iterations is too small to be seen here

tential spread of disease by live fish movement following the introduction of an exotic salmonid pathogen. Once a notifiable disease is suspected or confirmed, fish movements into or out of affected areas may be prohibited by placement of Designated Area Orders (DAO) through powers conferred by the Diseases of Fish Act (Anonymous 1937). The results clearly demonstrate that, unless a disease is detected and diagnosed quickly and measures to prevent spread implemented, a multi-focal outbreak involving many river catchments is highly likely. The results provide conservative estimates of the potential number of sites and catchments that may be affected because the model considered only one route of transmission - the anthropogenic movement of live fish. No attempt was made to simulate either the spread of disease within catchments (e.g. by water currents or migration of wild fish) or other routes of transmission between catchments that may be important for some diseases (including transmission on fomites, e.g. the movement of vehicles and people between sites). The frequency of movement between sites is not currently captured by the LFMD; therefore, it was not possible to model seasonality in live fish movement or to bias contacts towards more frequently supplied sites.

For many diseases, live fish movement has proved the most important route of spread. Trade in live fish and their gametes has resulted in the spread of fish pathogens within and between countries. For example, Gyrodactylus salaris and furunculosis were introduced to Norway by the import of salmon smolts from Sweden (Mo 1994) and Scotland (Egidius 1987) respectively. The parasitic nematode Anguillicola crassus was introduced into Germany with the importation of Asiatic eels Anguilla japonicus from Taiwan (Koops \& Haartmann 1989), and its subsequent spread through Europe is attributable largely to anthropogenic movement of European eels Anguilla anguilla for farming and restocking (Kirk 2003). Long distance spread of infectious salmon anaemia (ISA) in farmed salmon in Scotland was mainly due to movement of live fish in well-boats (Murray et al. 2002). White spot virus (WSV) was rapidly spread by the international movement of shrimp larvae (mainly Penaeus monodon), which resulted in the near collapse of the industry in a number of countries (Hill 2002). The large-scale movement of farmed fish in England and Wales, both between farms and from farms to rivers and still-waters for restocking, provides a route for the rapid dissemination of an introduced exotic disease.

The model described here provides output for both sites and river catchments. River catchments are areas joined by continuous freshwater flow, within which pathogens can disseminate on currents and are carried by wild or feral fish. Contacts between sites result in the spread of disease both within and between catchments. We placed a major emphasis on reporting results at the river catchment level. In the case of Gyrodactylus salaris (a highly fecund parasite with a short, direct life-cycle, which is extremely efficient at actively locating new hosts), disease spread within infected catchments in Norway proved practically impossible to control (Johnsen \& Jensen 1991). For this reason, the 

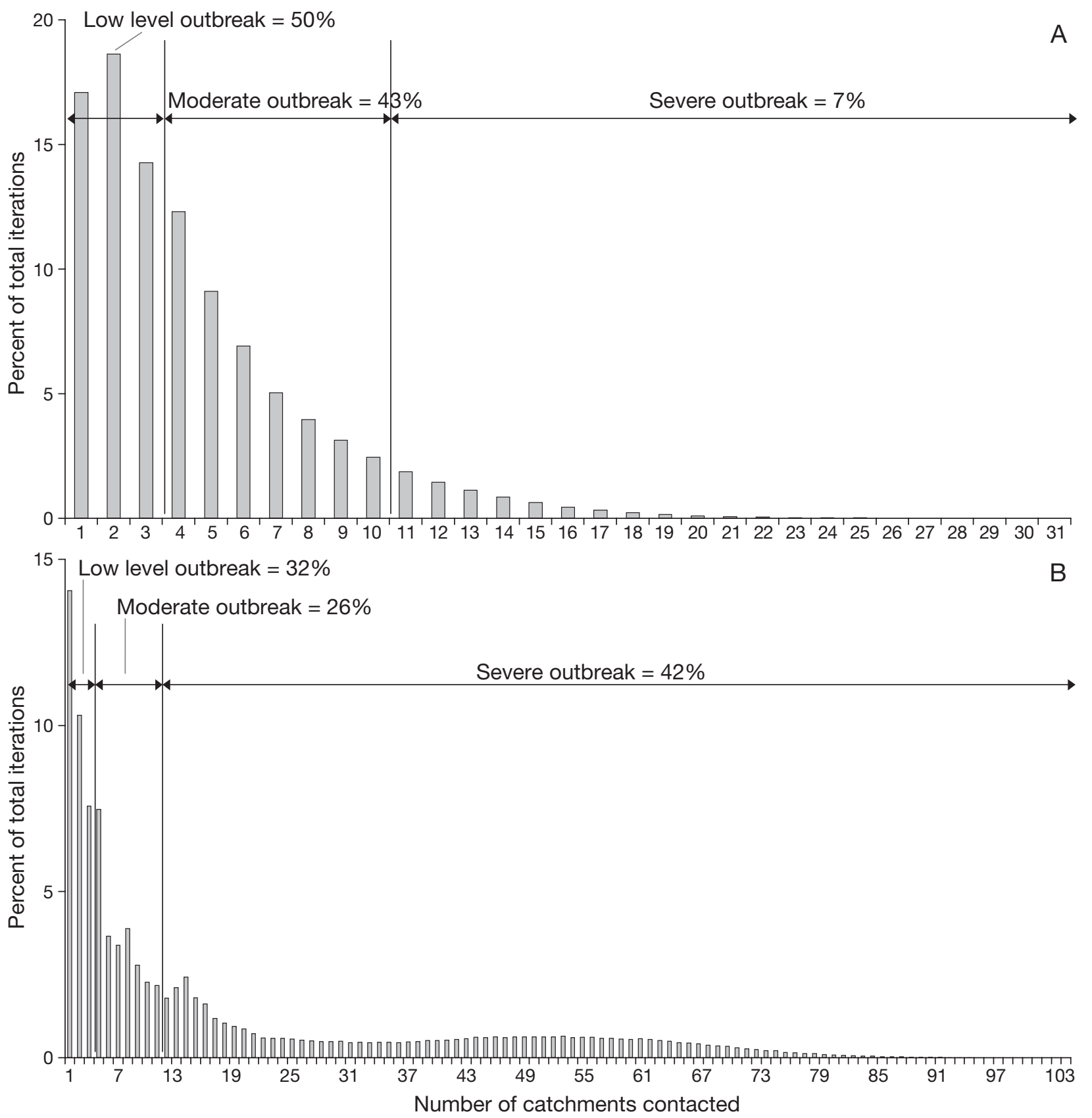

Fig. 5. Distribution of river catchments contacted after (A) 3 mo and (B) 12 mo from single index farm inputs. The $y$-axes extend to show the position of the worst-case scenarios (see Table 2) although the percentage of total iterations is too small to be seen here

management of this disease must operate largely at the catchment level and attempt to minimise spread of infection between catchments, which may be regarded as discrete epidemiological units.

Gyrodactylus salaris is also believed to have been transmitted by the migration of wild salmonids between Norwegian catchments through regions of low salinity (Høgåsen \& Brun 2003). Peeler et al. (2004) ranked this route as the third most important for the spread of $G$. salaris, after anthropogenic moments of salmonids and other species of live fish. Neighbouring catchments with shared estuaries may consequently need to be regarded as single units. Conversely, the separation of fish populations by dams, weirs and other (natural) barriers to wild fish migration may serve to limit the upstream component of disease transmission and possibly assist in the management of outbreaks at a sub-catchment level. The spread of viral diseases, including VHS and IHN, is sensitive to a minimum (disease-specific) infective concentration of pathogen, which is largely in- 
Table 3. Top 30 (of total 198) river catchments ranked by risk of contact by live fish movement. Total received contacts: output adjusted to remove index-case seeding. Relative position: risk relative to catchment with highest risk of contact by live fish movement

\begin{tabular}{|c|c|c|c|}
\hline Rank & $\begin{array}{l}\text { River } \\
\text { catchment }\end{array}$ & $\begin{array}{l}\text { Total received } \\
\text { contacts }\end{array}$ & $\begin{array}{l}\text { Relative } \\
\text { position }\end{array}$ \\
\hline 1 & Severn & 219747 & 100.0 \\
\hline 2 & Trent & 219470 & 99.9 \\
\hline 3 & Thames & 200894 & 91.4 \\
\hline 4 & Dee & 173179 & 78.8 \\
\hline 5 & Avon (Bristol) & 169749 & 77.2 \\
\hline 6 & Great Ouse & 166187 & 75.6 \\
\hline 7 & Ribble & 159217 & 72.5 \\
\hline 8 & Avon (Hampshire) & 153570 & 69.9 \\
\hline 9 & Mersey & 152349 & 69.3 \\
\hline 10 & Parrett & 149745 & 68.1 \\
\hline 11 & Ouse (Yorkshire) & 142463 & 64.8 \\
\hline 12 & Usk & 140256 & 63.8 \\
\hline 13 & Chelmer & 138694 & 63.1 \\
\hline 14 & Weaver & 131513 & 59.8 \\
\hline 15 & Medway & 128172 & 58.3 \\
\hline 16 & Arun & 128090 & 58.3 \\
\hline 17 & Tees & 116905 & 53.2 \\
\hline 18 & Stour (Dorset) & 111398 & 50.7 \\
\hline 19 & Ouse (Sussex) & 110923 & 50.5 \\
\hline 20 & Itchen & 109752 & 49.9 \\
\hline 21 & Taff & 109205 & 49.7 \\
\hline 22 & Don & 108830 & 49.5 \\
\hline 23 & Wyre & 106081 & 48.3 \\
\hline 24 & Washford River & 104420 & 47.5 \\
\hline 25 & Ogwen/Ddu & 103663 & 47.2 \\
\hline 26 & Tyne & 101951 & 46.4 \\
\hline 27 & Clwyd & 98126 & 44.7 \\
\hline 28 & Cleddau & 97286 & 44.3 \\
\hline 29 & Cefni & 96142 & 43.8 \\
\hline 30 & Lune & 93804 & 42.7 \\
\hline
\end{tabular}

fluenced within stocks by host density and between stocks by their geographical proximity. The role of wild fish in the dissemination of some diseases over long distances is likely to be less important than for G. salaris, and the establishment of sub-catchment epidemiological units (or zones) based on an assessment of population contact structure (farmed and wild) and their geographical proximity may be appropriate for the management of disease outbreaks in large or highly impacted river systems and provide an improved framework for future disease-specific models.

The model's results show that the time to diagnosis of an exotic or emerging disease in the UK will be a critical factor in determining its geographical spread before control and eradication efforts can be initiated. Gyrodactylus salaris causes significant mortalities in pre-smolt Atlantic salmon and was responsible for a $98 \%$ decline in infected river catchments in Norway over a time-scale of 2 to 5 yr (Johnsen \& Jensen 1991, Mo 1994). The parasite infects and completes its life cycle on rainbow trout at a much lower prevalence, causing no sign of clinical disease, and is likely to go unnoticed in a farmed trout population. If introduced to the UK, this parasite is unlikely to be detected until significant outbreaks have occurred in wild salmon stocks or population declines have been identified by survey, which could take up to $1 \mathrm{yr}$ or more.

For other exotic diseases, time to first detection is likely to be shorter. For example, an outbreak of VHS or IHN in a farmed fish stock reared at relatively high density and under close supervision is likely to be detected relatively quickly, and farmed (rainbow) trout would ideally act as sentinels for diseases affecting wild salmonid fish. However, although time to first mortality in a farmed population may be short, the definitive diagnosis of an exotic pathogen may take much longer. Testing for exotic viral diseases would be unlikely until it can be confirmed that endemic bacterial diseases with similar clinical symptoms (for example, enteric red mouth [ERM] or rainbow trout fry syndrome [RTFS]) is not involved, possibly following failure to respond to antibiotic treatment and subsequent resistance testing. Time to diagnosis of an outbreak of one of these viruses is then theoretically unlikely to be less than $3 \mathrm{wk}$. In addition, the impact of both VHS and IHN are temperature dependent. At relatively low temperatures (less than $12^{\circ} \mathrm{C}$ ), both diseases cause outbreaks in farmed rainbow trout populations with high numbers of mortalities (Bootland \& Leong 1999, Smail 1999). However, mortality is greatly attenuated at temperatures above $14^{\circ} \mathrm{C}$, so that the diagnosis of an outbreak occurring in summer may be further delayed by a number of weeks. Experience in Canada has shown that, in practice, time to diagnosis of IHN (determined by retrospective epidemiological investigation) following initial mortality may take several months (St-Hilaire et al. 2002).

\section{Contingency planning and surveillance}

There are 2 classes of model that may be developed for the prediction of disease spread: tactical and strategic. A tactical model is primarily used 'in peace time', when the disease is absent, to provide theoretical data that may, for example, be used for contingency planning. A strategic model is run in the face of a real outbreak and may be used to compare control strategies and thus inform decision-makers (e.g. as was the case during the UK FMD outbreak in 2001). This study will inform the contingency planning process for the introduction and control of exotic aquatic pathogens in England and Wales. Effective contingency plans must be based on realistic scenarios and it is important that they include a worst-case scenario. Our study indicates that contingency plans for England and Wales should 
be based on multi-focal outbreaks, involving many river catchments and a wide geographical spread, on first detection. The UK FMD epidemic in 2001 highlighted the need for planning to include a worst-case scenario. Prior to this episode, the FMD contingency plan was based on a maximum of 10 sites becoming infected before detection and identification of the disease (Anderson 2002). In reality, 57 farms were infected before the pathogen was identified (Gibbens et al. 2001). The model developed in the present study predicted a worst-case scenario affecting more than 500 sites in 104 catchments for a disease that may go undetected for $1 \mathrm{yr}$. This would include more than $50 \%$ of the salmonid farming industry in England and Wales, and would clearly have a massive impact on the wild salmon population, combined trout and salmon rod and net fisheries (valued at \$751 million in 2001 [Anonymous 2004]) and associated secondary leisure and tourist revenue. The control of live fish movements to prevent further disease spread would also have potentially severe economic consequences for fish farming businesses. Contingency planning for notifiable fish disease introduction must ensure that a response will accommodate the worst-case scenario of disease outbreak.

The contact structure between farm and non-farm sites indicates a wide range of trading practices. The customer and supplier profiles reveal a significant degree of heterogeneity, i.e. a large number of farms with a small number of contacts and a small number of sites with a large number of contacts. Heterogeneity in contact structure between farms can be very important in disease dissemination (Keeling et al. 2001, BigrasPoulin et al. 2004). Clearly, the establishment of an exotic disease in a farm supplying a large number of other farms is likely to result in rapid transmission of disease, making these sites epidemiologically important. The stochastic model described in this study captures the heterogeneity within the contact structure. Results from the model allowed us to rank both catchments and individual destinations by their likelihood of receiving a potentially infected consignment of live fish following the introduction of an exotic pathogen. In the future, this information will contribute to the development of risk-based disease surveillance.

\section{Future research}

Future development of the model should focus on the incorporation of disease-specific transmission and infection characteristics and the impact of local transmission routes, e.g. from infected farm populations to susceptible wild stocks in neighbouring rivers. Such developments would contribute to more informative outputs that may assist in the comparison of alternative disease-control strategies. Network theory has only recently been applied to the examination of contact structure in terrestrial livestock industries (BigrasPoulin et al. 2004, Webb \& Sauter-Louis 2004). Its potential to improve our understanding of the contact structure of the fish farming industry needs to be assessed.

Acknowledgements. This study was funded by the UK Department for Environment, Food and Rural Affairs (Defra), Contract FC1150.

\section{LITERATURE CITED}

Anderson I (2002) Foot and mouth 2001: lessons to be learnt inquiry report. The Stationery Office, London

Anonymous (1937) Diseases of Fish Act 1937. The Stationery Office, London

Anonymous (1975) Salmon and Freshwater Fisheries Act 1975. The Stationery Office, London

Anonymous (2004) Our nation's fisheries, the migratory and freshwater fisheries of England and Wales - a snapshot. The Environment Agency, Almondsbury

Bigras-Poulin M, Thompson A, Chriel M, Mortensen S, Griener M (2004) Network analysis of the Danish cattle and swine industry trade patterns as an evaluation of risk potential for disease spread: the heterogeneity issue. In: Reid SW, Menzies FD, Russell AM (eds) Proc Soc Veterinary Epidemiology and Preventive Veterinary 24-26 March 2004, Martigny, p 189-199

Bootland LM, Leong JC (1999) Infectious haematopoietic necrosis virus. In: Woo PTK, Bruno DW (eds) Fish diseases and disorders. Vol 3. Viral, bacterial and fungal infections. CABI, Wallingford, p 57-121

Davies G (2002) The foot and mouth disease (FMD) epidemic in the United Kingdom 2001. Comp Immunol Microbiol Infect Dis 25:331-343

des Clers S (1993) Modelling the impact of disease-induced mortality on the population size of wild salmonids. Fish Res 17:237-248

Egidius E (1987) Import of furunculosis to Norway with Atlantic smolts from Scotland. ICES CM 1987/F:8

Ferguson NM, Cummings DAT, Cauchemez S, Fraser C, Riley S, Meeyai A, Iamsirithaworn S, Burke DS (2005) Strategies for containing an emerging influenza pandemic in Southeast Asia. Nature 437:209-214

Gibbens JC, Sharpe CE, Wilesmith JW, Mansley LM, Michalopulou E, Ryan JBM (2001) Descriptive epidemiology of the 2001 foot-and-mouth disease epidemic in Great Britain: the first five months. Vet Rec 149:729-743

Green LE, Medley GF (2002) Mathematical modelling of the foot and mouth disease epidemic of 2001: strengths and weaknesses. Res Vet Sci 73:201-205

Hamel OS (2002) The dynamics and effects of bacterial kidney disease in Snake River spring chinook salmon (Oncorhynchus tshawytscha). Diss Abstr Int B Sci Eng 62:5446

Hill BJ (2002) National and international impacts of white spot disease of shrimp. Bull Eur Assoc Fish Pathol 22:58-65

Høgåsen HR, Brun E (2003) Estimating the risk of inter-river transmission of Gyrodactylus salaris by migrating Atlantic salmon smolts, estimated by Monte Carlo simulation. Dis Aquat Org 57:247-254 
Jalvingh AW, Nielen M, Maurice H, Stegeman AJ, Elbers ARW, Dijkhuizen AA (1999) Spatial and stochastic simulation to evaluate the impact of events and control measures on the 1997-1998 classical swine fever epidemic in The Netherlands. I. Description of the model. Prev Vet Med 42:271-295

Johnsen BO, Jensen AJ (1991) The Gyrodactylus story in Norway. Aquaculture 98:289-302

Keeling MJ, Woolhouse MEJ, Shaw DJ, Mattthews L and 6 others (2001) Dynamics of the 2001 foot and mouth epidemic: stochastic dispersal and a heterogeneous landscape. Science 294:812-817

Kirk RS (2003) The impact of Anguillicola crassus on European eels. Fish Manag Ecol 10:385-394

Klinkenberg D, Everts-van de Wind A, Graat EAM, de Jong MCM (2003) Quantification of the effect of control strategies on classical swine fever epidemics. Math Biosci 186:145-173

Koops H, Haartmann F (1989) Anguillicola infestations in Germany and in German eel imports. J Appl Ichthyol 1:41-45

Levy DA, Wood CC (1992) Review of proposed mechanism for sockeye salmon population cycles in Fraser River. Bull Math Biol 54:241-262

May RM, Anderson RM (1987) The transmission dynamics of HIV infection. Nature 326:137-142

Mo TA (1994) Status of Gyrodactylus salaris problems and research in Norway. In: Lewis JW (ed) Parasitic diseases of fish. Samara Publishing, Tresaith p 43-48

Murray A, Smith R, Stagg R (2002) Shipping and the spread of infectious salmon anemia in Scottish aquaculture. Emerg Infect Dis 8:1-5

Editorial responsibility: Julie Bebak,

Auburn, Alabama, USA
Paisley LG, Karlsen E, Jarp J, Mo TA (1999) A Monte Carlo simulation model for assessing the risk of introduction of Gyrodactylus salaris to the Tana river, Norway. Dis Aquat Org 37:145-152

Peeler EJ, Gardiner R, Thrush MA (2004) Qualitative risk assessment of routes of transmission of the exotic fish parasite Gyrodactylus salaris between river catchments in England and Wales. Prev Vet Med 64:175-189

Smail DA (1999) Viral haemorrhagic septicaemia. In: Woo PTK, Bruno DW (eds) Fish diseases and disorders. Vol 3. Viral, bacterial and fungal infections. CABI, Wallingford, p 123-147

St-Hilaire S, Ribble CS, Stephen C, Anderson E, Kurath G, Kent ML (2002) Epidemiological investigation of infectious hematopoietic necrosis virus in salt water net-pen reared Atlantic salmon in British Columbia, Canada. Aquaculture 212:49-67

van der Hof S, Wallinga J, Widdowson MA, Conyn-van Spaendonck MAE (2002) Protecting and vaccinating population in the face of a measles epidemic: assessing the impact of adjusted vaccination schedules. Epidemiol Infect 128:47-57

Webb CR, Sauter-Louis CM (2004) Investigations into the contact structure of the British sheep population. In: Reid SW, Menzies FD, Russell AM (eds) Proc Soc Veterinary Epidemiology and Preventive Medicine, 24-26 March 200, 4 Martigny, p 10-20

Woolhouse MEJ, Chase-Topping M, Haydon DT, Friar J and 8 others (2001) Foot-and-mouth disease under control in the UK. Nature 411:258-259

Submitted: January 13, 2005; Accepted: June 21, 2006

Proofs received from author(s): September 14, 2006 